\title{
Reply to 'Discussion of oxygen isotopes in ophicalcites: an ever-lasting controversy?' by R. Coltat, Ph. Boulvais, Y. Branquet, M. Poujol, P. Gautier and G. Manatschal
}

\author{
Daniel Bernoulli ${ }^{1} \cdot$ Helmut Weissert ${ }^{1}[0$
}

Received: 20 December 2020 / Accepted: 30 December 2020

(c) The Author(s) 2021, corrected publication 2021

Our publication 'Oxygen isotopes in ophicalcites: an everlasting controversy?' in this journal (Bernoulli and Weissert 2020) discussed the interpretation of oxygen isotopes in Alpine ophicalcites and deep-sea sediments. Based on the remarkable correlation of the isotope values with the degree of Alpine metamorphism (Bernoulli and Weissert 2020: Fig. 4), we argued that the oxygen isotope signatures measured in ophicalcites and pelagic limestones were equilibrated during Alpine metamorphism. They do not reflect the temperatures of carbonation of the serpentine host rocks or the formation of calcite in veins and cements or of marine biogenic calcite in pelagic sediments associated with the ophicalcites. In particular, we doubted the interpretation of Coltat et al. (2019a) that the oxygen isotope values in the ophicalcites of South-Penninic Platta Nappe at Falotta faithfully recorded the temperature of carbonation and of the emplacement of calcite veins in the serpentinite host rock, estimated by Coltat et al. (2019a) at $\sim 100^{\circ} \mathrm{C}$. In contrast, the near-identical oxygen isotope values in the ophicalcites and in the overlying Upper Jurassic-Lower Cretaceous pelagic limestones clearly indicate that the Middle Jurassic ophicalcites and the overlying sediments underwent together one or more thermal events resetting their oxygen isotope signatures, which in contrast were related by Coltat et al. (2019a) exclusively to a 'single, sudden event' of hydrothermal activity during the Middle Jurassic.

We do not doubt the importance of hydrothermal fluids in the formation of ophicalcites (Früh-Green et al. 1990), nor that at Falotta carbonation of the serpentinite host rock occurred during the exhumation of mantle rocks along low-angle detachment faults (e.g. Desmurs et al. 2001), nor do we doubt deformation associated with ophicalcite

Helmut Weissert

helmut.weissert@erdw.ethz.ch

1 Department of Earth Sciences, Swiss Federal Institute of Technology, CH-8092 Zürich, Switzerland formation. We only relate the present-day oxygen values observed in the ophicalcites and associated sediments to Alpine metamorphism. ${ }^{1}$

Coltat et al. (2019a, b, 2020) regard the localities Falotta and Marmorera-Cotschens as singularities where practically no Alpine fluid exchange or recrystallization occurred. However, we doubt that no Alpine recrystallization should have occurred at Falotta [see Fig. 5 in Bernoulli and Weissert (2020) for an example in the less metamorphic Totalp Nappe] and that no fluids circulated during Alpine deformation and metamorphism. That all calcite crystals in the ophicalcites at Falotta show identical $\delta^{18} \mathrm{O}$-values, irrespective of their habit (Coltat et al. 2019a:185, 2020), is, in our view, much better explained by Alpine metamorphic re-equilibration than by one single hydrothermal event.

Coltat et al. (2021) write that isotopic re-equilibration 'could be partly true' for post-rift sediments but they do not explain why this should be only partly true. We do not know of any pelagic limestones of Late Jurassic-Early Cretaceous age outside orogens showing oxygen isotope values of -6 to $-14 \%$. These values can only be the result of metamorphic overprint. In addition, ophicalcites and pelagic limestones consistently show a parallel evolution along the entire transect from northern Graubünden to Val Malenco and all pelagic sediments show re-equilibrated values along it (Fig. 1). We are well aware that the oxygen isotope values are difficult to interpret and that different processes at different times have altered them; however, close correlation with metamorphic grade shows that re-equilibration occurred during Alpine metamorphism.

Coltat et al. (2020) distinguish between 'cooler ophicalcites' in the South-Penninic nappes and the ophicalcites of the Platta Nappe. However, at other localities like Arosa, the

\footnotetext{
$\overline{1}$ We are well aware that this metamorphism occurred during the accretion of the upper plate units of Alpine subduction that were not subducted (see e.g. McCarthy et al. 2018). We said that subduction started in the Late Cretaceous, but not that the Platta Nappe was subducted, as insinuated by Coltat et al. (2021).
} 


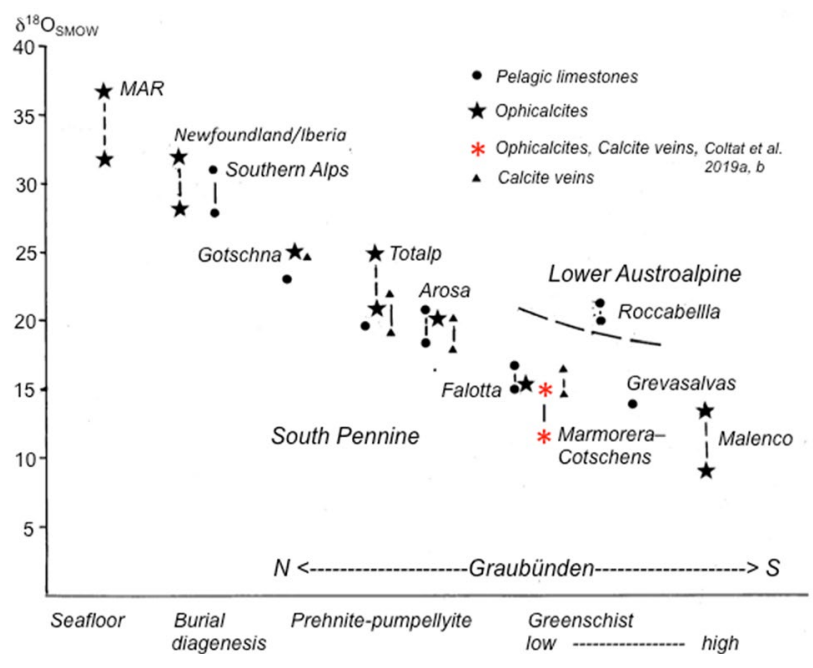

Fig. 1 Correlation between O-isotope composition of ophicalcites and oceanic sediments, and metamorphic grade along a transect of the Penninic/Australpine boundary zone, Graubünden. From Bernoulli and Weissert (2020: Fig. 4), with the oxygen isotope values from Marmorera-Cotschens (Coltat et al. 2019b) added

ophicalcites co-occur with basalts, similar to the ophicalcites at Falotta (Platta Nappe). Likewise evidence for hydrothermal activity is seen in 'cold ophicalcites' at Totalp and Gotschna where hydrogrossular, identified in ophicalcites (Totalp, Früh-Green et al. 1990), is pointing at hydrothermal temperatures of up to $200{ }^{\circ} \mathrm{C}$ where no basalts occur.

In our paper (Bernoulli and Weissert 2020), we did not discuss the data from Marmorera-Cotschens. At these outcrops, Coltat et al. (2019b) measured in the calcite veins $\delta^{18} \mathrm{O}_{\mathrm{V} \text {-SMOw }}$ values of $\sim 12 \%$, i.e. $4 \%$ o lower than those measured at Falotta. We included these values now in our Fig. 1; they do not deviate much from the general trend in the $\mathrm{N}-\mathrm{S}$-transect and might reflect a somewhat higher grade of Alpine metamorphism: they are still in the range of greenschist metamorphism indicated for this locality by Ferrero Mählmann (1996, 2001). In fact, the outcrop at Marmorera is about $500 \mathrm{~m}$ deeper in the tectonic edifice than Falotta. In addition, the Late Jurassic-Early Cretaceous $\mathrm{U}-\mathrm{Pb}$ age $(144 \pm 13 \mathrm{Ma})$ in calcite from Cotschens is much younger than the intrusion of the gabbros ( $161 \pm 1 \mathrm{Ma}$, Schaltegger et al. 2002) to which hydrothermal activity is related according to Coltat et al. (2019a). Even though Epin et al. (2019) report the intrusion of a lone magmatic sill in the Lower Cretaceous Aptychus Limestone near Bivio, the significance of this Late Jurassic-Early Cretaceous numerical age is most uncertain. It is also much younger than the onset of deposition of the syn- to post-rift radiolarites that, however, in Graubünden is not precisely dated. An upper age bracket of radiolarite deposition is given by the age of the overlying Aptychus (Calpionella) Limestone (late Tithonian-Berriasian) dated in the Davos region (Weissert 1975), a lower one by the general age of the onset of radiolarite deposition in the Liguria-Piemontese realm beginning in the Bathonian (168-166 Ma, Bill et al. 2001).

'No low-temperature ophicalcites have been found yet in the Alps, suggesting that their original low-temperature signatures have been obliterated by Alpine metamorphism' (Bernoulli and Weissert 2020). Indeed no ophicalcites with high $\delta^{18} \mathrm{O}_{\mathrm{V}-\text { SMOw }}$ values like of those recorded at the MAR or at the Newfoundland or Iberian margins are reported from the Alps, but could be expected if no or minor thermal alteration had taken place. We never excluded the existence of higher-temperature hydrothermal carbonates in presentday oceans as cited by Coltat et al. (2021); however, the existence of such higher-temperature carbonates in presentday oceans is no independent argument against Alpine reequilibration of the oxygen isotopes. In fact also oxygen isotopes of 'higher-temperature' ophicalcites, if present at Falotta or Cotschens, could still have been re-equilibrated during greenschist-grade Alpine metamorphism.

Coltat et al. (2019a, b, 2020) think that the near-identical oxygen isotope composition in ophicalcites and the close correlation of these values and the Alpine metamorphic grade are fortuitous, admitting only that, 'on some sites postrift sediments display oxygen isotope signatures roughly similar to those of ophicalcites and may indeed reflect a local Alpine overprint' (Coltat et al. 2021). In particular, the overturned succession in Val Savriez (Weissert and Bernoulli 1985: Fig. 4) is cited to illustrate the particular circumstance under which a local Alpine overprint might occur. However, tectonically overturned successions are ubiquitous in the Platta Nappe and the Arosa Zone (e.g. Gotschna, Weissfluh/Davos) and show the same degree of metamorphism as their surroundings. This rather reflects the importance of Alpine tectonics related to 'subduction initiation and accretion' during the Late Cretaceous followed by Cenozoic collision (McCarthy et al. 2018). If the sediments at Roccabella display higher $\delta^{18} \mathrm{O}_{\mathrm{V}-\mathrm{SMOw}}$ values it is because this locality is situated higher in the nappe pile in a Lower Austroalpine unit (Bernoulli and Weissert 2020: Fig. 2) of lower Alpine metamorphic grade (Ferrero Mählmann 1996, 2001).

We think that the principle of simplicity (Occam's Razor) is still a valuable tool in science and that our correlation of oxygen isotope composition and metamorphic grade in ophicalcites and sediments is not fortuitous but reflects a common cause. The 'ever-lasting controversy' may, therefore, not be solved.

Funding Open access funding provided by Swiss Federal Institute of Technology Zurich. 
Open Access This article is licensed under a Creative Commons Attribution 4.0 International License, which permits use, sharing, adaptation, distribution and reproduction in any medium or format, as long as you give appropriate credit to the original author(s) and the source, provide a link to the Creative Commons licence, and indicate if changes were made. The images or other third party material in this article are included in the article's Creative Commons licence, unless indicated otherwise in a credit line to the material. If material is not included in the article's Creative Commons licence and your intended use is not permitted by statutory regulation or exceeds the permitted use, you will need to obtain permission directly from the copyright holder. To view a copy of this licence, visit http://creativecommons.org/licenses/by/4.0/.

\section{References}

Bernoulli D, Weissert H (2021) Oxygen isotopes in ophicalcites: an ever-lasting controversy? Int J Earth Sci 110:1-8. https://doi.org/ 10.1007/s00531-020-01934-5

Bill M, O’Dogherty L, Guex J, Baumgartner PO, Masson H (2001) Radiolarite ages in Alpine-Mediterranean ophiolites: Constraints on the oceanic spreading and the Tethys-Atlantic connection. Geol Soc Amer Bull 113:129-143

Coltat R, Boulvais P, Branquet Y, Collot J, Epin ME, Manatschal G (2019a) Syntectonic carbonation during syn-magmatic mantle exhumation at an ocean-continent transition. Geology 47:183-187

Coltat R, Branquet Y, Gautier P, Rodriguez HC, Poujol M, Pelleter E, McClenaghan S, Boulvais Ph, Manatschal G (2019) Unravelling the root zone of ultramafic-hosted black smokers-like hydrothermalism from an Alpine analog. Terra Nova. https://doi.org/10. 1111/ter.12427

Coltat R, Boulvais Ph, Branquet Y, Poujol M, Gautier P, Manatschal G (2021) Discussion to "Oxygen isotopes in ophicalcites: an everlasting controversy?". Int J Earth Sci. https://doi.org/10.1007/ s00531-021-01983-4
Desmurs L, Manatschal G, Bernoulli D (2001) The Steinmann Trinity revisited: mantle exhumation and magmatism along an ocean-continent transition, the Platta nappe, eastern Switzerland. In: Wilson RCL, Whitmarsh RB, Taylor B, Froitzheim N (eds) Non-volcanic rifting of continental margins: a comparison of evidence from land and sea. Geol Soc (London) Spec Publ 187:235-266

Epin ME, Manatschal G, Amman M, Ribes C, Clausse A, Guffon T, Lescanne M (2019) Polyphase tectono-magmatic evolution during mantle exhumation in an ultra-distal domain: example of the fossil Platta ophiolite, SE Switzerland. Int J Earth Sci 108:2443-2467. https://doi.org/10.1007/s00531-019-01772-0

Ferreiro-Mählmann R (1996) Das Diagenese-Metamorphose-Muster von Vitrinitreflexion und Illit-Kristallinität in Mittelbünden und im Oberhalbstein, Teil 2: Korrelation kohlenpetrographischer und mineralogischer Parameter. Schweiz Mineral Petrogr Mitt 76:23-46

Ferreiro-Mählmann R (2001) Correlation of very low grade data to calibrate a thermal maturity model in a nappe tectonic setting, a case study from the Alps. Tectonophysics 334:1-33

Früh-Green GL, Weissert H, Bernoulli D (1990) A multiple fluid history recorded in Alpine ophiolites. J Geol Soc (London) 147:959-970

McCarthy A, Chelle-Michou C, Müntener O, Arculus R, Blundy J (2018) Subduction initiation without magmatism: The case of the missing Alpine magmatic arc. Geology 46:1059-1062

Schaltegger U, Desmurs L, Manatschal G, Müntener O, Meier M, Frank M, Bernoulli D (2002) Transition from a rifted continental margin to a slow spreading system: field and isotopic constraints from a Tethyan ophiolite. Terra Nova 14:156-162

Weissert H (1975) Zur Geologie der Casanna bei Klosters. Eclogae Geol Helv 68:222-229

Weissert H, Bernoulli D (1985) A transform margin in the Mesozoic Tethys: evidence from the Swiss Alps. Geol Rdsch 74:665-679 